УДК 378.147 .31

DOI 10.11603/2411-1597.2020.2.11232

\title{
ПРОБЛЕМА ГУМАНІТАРНОЇ ПІДГОТОВКИ МАЙБУТНІХ ФАХІВЦІВ МЕДИЧНОЇ ГАЛУЗІ
}

\author{
В. Й. Кульчицький ${ }^{1}$, Л. М. Невінська ${ }^{2}$ \\ ${ }^{1}$ Тернопільський національний медичний університет \\ імені І. Я. Горбачевського МОЗ Украӥни \\ ${ }^{2}$ Комунальне некомерційне підприємство “Міська дитяча клінічна лікарня м. Львова"
}

У статті розглянуто проблему гуманітарної підготовки майбутніх фахівців медичної галузі на засадах міждисциплінарної інтеграції.

\section{THE PROBLEM OF HUMANITARIAN TRAINING OF THE FUTURE MEDICAL INDUSTRY PROFESSIONALS}

\author{
V. Y. Kulchytskyj ${ }^{1}$, L. M. Nevinska ${ }^{2}$ \\ ${ }^{1}$ I. Horbachevsky Ternopil National Medical University \\ ${ }^{2}$ Lviv City Children's Clinical Hospital
}

The article deals with the problem of humanitarian training of future medical professionals on the basis of interdisciplinary integration.

Вступ. Початок XXI століття приніс в українську освіту кардинальні зміни. Змістове наповнення того, що вивчали донедавна у закладах вищої освіти, зазнало суттєвих змін. Навчитися орієнтуватися в потоці інформації та досягти сучасного розуміння фундаментальних основ професійної діяльності вимагає від майбутніх фахівців медичної галузі відмінного володіння професійними компетенціями і гуманітарного світогляду.

У системі вищої медичної освіти спостерігається тенденція до зниження позитивної мотивації щодо вивчення гуманітарних дисциплін, оскільки студент, вступивши до вищого медичного навчального закладу, налаштований насамперед на здобуття професійних знань, умінь та навичок. У результаті тільки незначний відсоток майбутніх медичних працівників вільно володіє мовою конструктивного діалогу чи полілогу, вміє правильно й доступно формулювати професійну думку та суспільно-громадську позицію, а як результат - не може знайти себе у професії та в соціумі, натомість часто позиціонує себе і своє майбутнє поза межами України або взагалі не пов'язує своє майбутнє з медициною через відсутність професійної мотивації.

(с) В. Й. Кульчицький, Л. М. Невінська, 2020
Саме тому, недостатнє уявлення про національну ідею та їі реалізацію в системі вищих медичних закладів освіти, зокрема у викладанні гуманітарних дисциплін, впливає на формування світогляду майбутньої медичної еліти України. У цьому контексті не йдеться про професійну відповідність, а насамперед про особистісне самовираження майбутнього фахівця медичної галузі [1].

Основна частина. Питання гуманітарної підготовки майбутніх медичних працівників $\epsilon$ актуальним, однак не новим для сучасної освіти. Вважаємо за доцільне звернутися до розгляду накопиченого досвіду. Насамперед, необхідно відзначити, що формування духовних цінностей у вищій школі засобами гуманітарних наук досліджувала А. Ярошенко [2]. Науковцем О. Плавуцькою запропоновано педагогічні умови розвитку духовних цінностей особистості у процесі вивчення дисциплін гуманітарного циклу [3]. Ж. Свиренко розкрила суть гуманізму як відображення морально-етичного закону людського буття, як специфічної властивості гуманістичного образу особистості; проаналізувала загальнокультурні цінності, змістові, світоглядні можливості предметів гуманітарного циклу щодо виховання гуманізму в студентів закладів вищої освіти (3ВО) [4]. Актуальною для нашо- 
го дослідження є думка В. Гриньової, яка справедливо стверджує, що фахівець у новому столітті - це духовно багата особистість, яка володіє творчими здібностями, віддана своїй справі, захоплена нею, розуміє необхідність розвитку духовних потреб пізнання й самопізнання, краси, спілкування, пошуку сенсу життя, щастя, має високі ідеали; орієнтована на загальнолюдські цінності, світову й національну духовну культуру і включає знання з основ філософії, етики, естетики, людинознавства й інших гуманітарних предметів [5], що свідчить про посилення ролі гуманітарних дисциплін у вищій медичній освіті.

Більшість сучасних дослідників переконана, що гуманітарні науки повинні надавати знання, необхідні не лише для роботи за фахом, а й такі, які дадуть змогу соціалізуватися майбутньому фахівцю-медику в трудовому колективі та суспільстві в цілому. На думку вчених, результатом гуманітарної підготовки у ЗВО повинна стати поява на ринку праці фахівця креативного, гуманного, інтелігентного, самодостатнього [6]. як відзначають у дослідженнях науковці Н. Нерух та І. Сопівник [7], гуманітарні дисципліни узагальнюють звернення до професійної компетентності сучасного фахівця; моральних якостей, активної громадянської позиції; вміння працювати в умовах ринкових відносин; працелюбності та господарності [8].

У сучасних умовах важливо розуміти вагому роль гуманітарних дисциплін як цілісної і світоглядної системи людських знань у формуванні особистості майбутнього фахівця медичної галузі, який, осмислюючи час, в якому живе, і головні питання, що їх поставила сучасна суспільна практика, маючи при цьому певну суму знань і навичок, зможе їх адекватно вирішувати, доводячи, що ми створюємо державу, в якій кожен $є$ не тільки об'єКтом, а й суб'єКтом суспільного розвитку [9].

Аналізуючи європейські інтеграційні процеси, потрібно усвідомлювати, що світоглядний принцип європейської освіти - це єдність у розмаїтті. Європа шукає не уніфікації, а мультикультуралізм, допускаючи варіанти входження у свій простір з урахуванням національної специфіки системи освіти.

Саме тому, науковці вважають, що XXI століття буде гуманітарним. «XXI століття $\epsilon$ часом після століття XX з його тотальною дегуманізацією суспільства й мас. Наше сторіччя потенційно має цікавість до людяності, до окремої людини та всього, що становить їі сутність. А сутність людини формується не тільки їі практичними вміннями, навичками, а й тими якостями, які наповнюють їі духовність, світогляд. Це те, що дають гуманітарні науки, виховує гуманітарна освіта» [10].

Основою формування професії медичного працівника, визначальною їі рисою є моральність, гуманність. Парадигму гуманітарних проблем медичної професії відображає гуманітарний аспект медичної освіти. Це такі проблемні питання, як: взаємостосунки фахівця медичної галузі й пацієнта та його родичів, цілісного підходу в профілактиці та лікуванні захворювань, питання медичного права і т. д. [11]. Тому гуманітарна освіта для студента - майбутнього медичного працівника є тим фактором, що визначає вектор його розвитку як фахівця та як особистості.

Таким чином, можна виділити три основних причини, які обґрунтовують необхідність вивчення гуманітарних дисциплін та отримання гуманітарної підготовки майбутніми фахівцями медичної галузі:

1. Здатність мислити. Завдяки розвідкам у галузі гуманітарних дисциплін ми вчимося мислити творчо і критично, роздумувати і ставити запитання. Такі навички дають нам змогу отримувати нові відомості з усіх сфер життя.

2. Розуміння світу. Дослідження людського досвіду накладається на наші знання про світ. Крізь призму досліджень науковців-гуманітаріїв ми вивчаємо культурні цінності представників різних культур, вникаємо в суть зразків мистецтва, історичних процесів.

3. Можливість прогнозування суспільно-політичних та культурно-історичних процесів. Сьогодні гуманітарні знання є підґрунтям для вивчення та розуміння досвіду людства. Дослідження в галузі філософії приводять до роздумів над питаннями етики. Вивчення іншої мови допомагає відчути «смак» спільних рис різних культур. Засвоєння історичного матеріалу сприяє кращому розумінню минулого, водночас, створюючи зрозумілу картину майбутнього [12].

Висновки. Відтак, незважаючи на той факт, що у сфері гуманітарної підготовки майбутніх фахівців медичної галузі у ЗВО накопичено значний теоретичний досвід, але його слід практично застосувати в освітній процес. Гуманітарні дисципліни, хоча й не $\epsilon$ профілюючими, але повинні розглядатися майбутніми фахівцями-медиками і науково-педагогічними працівниками як обов'язкові для формування конкурентоспроможної на вітчизняному та зарубіжному ринку праці; всебічно розвиненої особистості.

Окрім того, саме гуманітарна освіта формує людину мислячу, розум якої вільний від стереотипів та 
загальноприйнятих штампів. Медичний працівник, як фахівець, який працює безпосередньо з людиною, зобов'язаний мати високий рівень підготовки, перш за все, із загальноосвітніх, зокрема гуманітарних дис-

\section{СПИСОК ЛІТЕРАТУРИ}

1. Шутак Л. Б. Роль і місце гуманітарних дисциплін у процесі підготовки майбутніх медиків / Л. Б. Шутак, Г.В.Навчук // Лінгвістика. Лінгвокультурологія. - 2013. № 6. - С. 94-103.

2. Ярошенко А. О. Формування духовних цінностей в сучасній вищій школі засобами гуманітарних наук (соціально-філософський аспект) : дис. ... канд. філос. наук : спец. 09.00.03 / А. О. Ярошенко. - К., 2003. - 320 с.

3. Плавуцька О. П. Педагогічні умови розвитку духовних цінностей студентів у процесі вивчення дисциплін гуманітарного циклу : автореф. дис. на здобуття наук. ступеня канд. пед. наук : 13.00 .07 / О. П. Плавуцька. - Тернопіль, 2010. - 20 c.

4. Свиренко Ж. С. Виховання гуманізму в студентів вищих технічних навчальних закладів у процесі вивчення предметів гуманітарного циклу : дис. ... канд. пед. наук : спец. 13.00.07 / Ж. С. Свиренко. - Бердянськ, 2009. - 184 с.

5. Гриньова В. М. Педагогічна культура майбутнього вчителя як підґрунтя його успішної професійної діяльності / В. М. Гриньова // Актуальні проблеми державного управління, педагогіки та психології : збірник наукових праць ХНТУ. - 2011. - Вип. 2 (5). - С. 235-241.

6. Ашмарин И. И. Гуманитарная составляющая университетского научно-технического образования // И. И. Ашмарин, Е. Д. Клементьев // Высшее образование в России. - 2009. - № 1. - С. 3-14. циплін. Отож, виховуючи високоосвічених фахівців медичної галузі, ми формуємо морально-патріотичне суспільство, першою і головною цінністю якого $€$ людина.

7. Сопівник І. В. Формування громадянськості студентів вищих аграрних навчальних закладів: автореф. дис. на здобуття наук. ступеня канд. пед. наук : 13.00.07 / І. В. Сопівник. - Тернопіль, 2006. - 24 с.

8. Нерух Н. В. Формування гуманістичної спрямованості майбутніх агрономів в процесі вивчення соціогуманітарних дисциплін : дис. ... канд. пед. наук : спец. 13.00.04 / H. В. Нерух. - К., 2009. - 296 с.

9. Шевчук Т. Є. Викладання дисципліни «Соціологія» 3 використанням методу опорних конспектів / Т. Є. Шевчук // Нова педагогічна думка: науково-методичний журнал. - 2013. - № 1 (73). - С. 18-23.

10. URL : http://tyzhden.ua/ Society/130684.

11. Микиртичан Г. Л. Гуманитарная составляющая высшего медицинского образования [Электронный ресурс] / Г. Л. Микиртичан. - Режим доступа : http://www. zdrav.ru/library/publications/ detail.php?ID=1906.

12. Яцишина О. В. Гуманітарна підготовка: проблема визначення та роль у професійній освіті майбутнього лікаря / О. В. Яцишина // Образование и наука на XXI век 2013 : материалы IX Международной научно-практической конференции (София, 17-25 октября, 2013). - София, 2013. - Т. 7. Педагогические науки. - С. 61-64.

Отримано 25.03.20 